Growers' Association (January 1951 ; obtainable from the Association at Yaxley, Peterborough ; 5s.). It describes how eelworms belonging to the groups Ditylenchus and Rhabditis may damage mushroom beds by the destruction of mycelium, leaving bare patches, and by the distribution of disease-producing bacteria. They may be carried to the beds initially on the casing soil, but also persist between crops upon the bed boards. Satisfactory control has been obtained by heating the houses uniformly, after filling, to $140^{\circ} \mathrm{F}$. for a day or more. Steaming the house for several hours after the temperature begins to fall helps with the sterilization of boarding. The temperature should not reach $150^{\circ} \mathrm{F}$. or moulds may bring another kind of damage. Formaldehyde treatment is ineffective as a control, and chloropicrin has given variable results.

\section{Prehistoric Cave Paintings in South Africa}

THE March issue of the South A frican Archoeological Bulletin contains an article by J. R. Harding on his investigations at a rock-shelter site about six miles to the east of Bethlehem, Orange Free State. Some poor paintings occur, the most recent apparently being the figure of a Bush woman. The industries excavated range from Smithfield $C$ without pottery to levels where pottery appears, to a latest Smithfield $C$ with strong Bantu influence, with even some evidence of true Bushman occupation. It seems scarcely likely that any of the paintings are older than the industries unearthed, and none of these can be assigned to a very remote period. The paintings themselves are poor specimens and not well drawn.

\section{Entomological Testing Methods}

IN 1948, the Entomology Subcommittee of the Chemical - Biological Coordination Center, U.S. National Research Council, obtained information on insecticide-testing from numerous laboratories and the results were distributed to participants. The Subcommittee planned to continue this successful survey. Recently, after discussions with the American Association of Economic Entomologists and others, it was decided that a book on testing methods in entomology would be more useful and, in April 1951, Dr. Harold H. Shepard, U.S. Department of Agriculture, was appointed editor. The book will include toxicological and screening methods used by entomologists in the United States and other countries and will contain descriptions of methods detailed enough to permit them to be duplicated. It will be published by the National Research Council and sold at cost price. Those who wish to participate in this project by furnishing descriptions of the test methods which they use should apply for forms to Dr. Raimon L. Beard, Chairman, Entomology Subcommittee, Chemical-Biological Coordination Center, National Research Council, 2101 Constitution Avenue, Washington $25, \mathrm{D} . \mathrm{C}$.

\section{Cartography of the Antarctic}

RECENT American and Norwegian work, as well as the discoveries of the German Swabenland expedition in 1939, are incorporated in a new map of the Antarctic by H. P. Kosack in Petermanns Mitteilungen. (95, No. 2 ; 1951). The map, which is in blue and brown, is on a scale of $1: 11,250,000$, and shows surface and bathymetrical relief in $1,000-\mathrm{m}$. form lines. Notes in the margin give the location of the British, Argentine, Chilean and French stations. Names in the main follow the English usage; but there are many new German names in New Swabenland and American names in Marie Byrd Land and in the Ellsworth plateau. Accompanying this map is one on the scale of $1: 4,000,000$ of New Swabenland and adjoining territories between Coats Land and Princess Ragnhild Coast. A full and critical list of cartographical sources is given. Another article in the same number of this German publication, "Zur Frageder Namengebung in der Antarktis", by Dr. J. Georgi, gives the sources of German names in the Antarctic map with a full list of such names. This is most useful and should be done for all names in the Antarctic before there are no members left of the various expeditions who can supply the information. Already the origin of several German names of the 'nineties are untraceable.

\section{The Chillingham Cattle}

Fon thirty years prior to 1947 the strength of the famous herd of cattle in the park at Chillingham Castle in Northumberland had been fairly constant at about 35-40 head. After the severe winter of 1947, thirteen survived, of which eight were cows, five were bulls and none was young. For eighteen months or so no calf was born, and it was feared that the king bull might have become infertile; it was thought that this bull would have to be destroyed to save the herd from extinction. Fortunately, two bull calves arrived and, later, four heifers. The herd now consists of three bulls, seven cows, two bull calves and four heifer cows and now seems to be re-establishing itself. To help in the preservation of this valuable herd, which has almost certainly been at Chillingham Park since 1240, in 1939 an Association was formed. Those who wish to view the herd and apply for membership of the Association should write to the Secretary, Chillingham Wild Cattle Association, Ltd., Estate Office, Chillingham, Alnwick, Northumberland, for further information.

\section{World Metallurgical Congress}

A Wortd Metallurgical Congress will be held in Detroit, Michigan, during October 14-19. It is expected that more than five hundred individuals from some twenty different countries will attend, in addition to American metallurgists. The Congress has the full support of the Economic Cooperation Administration of Washington, D.C. A technical assistance programme covering visitors from E.C.A. countries has been established at the request of the Organization for European Economic Cooperation. Foreign visitors are expected to arrive about September 15 and will spend approximately five weeks in the United States. During the first four, they will be divided into eight groups participating in a series of study tours to industrial, government and educational institutions to observe at first hand the scientific, industrial and educational advances that have taken place in the United States during the past few years. Dr. Zay Jeffries, of Pittsfield, Mass., retired vice. president of the General Electric Company, and a past president of the American Society for Metals, has been appointed director general of the Congress. Early in the Congress a comprehensive summary of raw materials of the world as they relate to the metal industry will be presented. Visiting authorities from various countries will discuss problems of conservation, utilization and substitution of strategic metals. The industrial study tours planned in connexion with the Congress are being arranged in eight categories of 